\title{
Sunlight-induced DNA damage and resistance in natural viral communities
}

\author{
Markus G. Weinbauer ${ }^{1}$, Steven W. Wilhelm ${ }^{2, *}$, Curtis A. Suttle ${ }^{3, * *}$, Ralph J. Pledger ${ }^{4}$, \\ David L. Mitchell ${ }^{4}$
}

${ }^{1}$ National Research Centre for Biotechnology, Division Microbiology, Mascheroder Weg 1, D-38124 Braunschweig, Germany

${ }^{2}$ National Water Research Institute, Canada Centre for Inland Waters, 867 Lakeshore Road, Burlington, Ontario L7R 4A6, Canada

${ }^{3}$ Departments of Earth and Ocean Sciences (Oceanography), Botany, and Microbiology and Immunology, The University of British Columbia, 6270 University Boulevard, Vancouver, British Columbia V6T 1Z4, Canada

${ }^{4}$ The University of Texas MD Anderson Cancer Center, Department of Carcinogenesis, Park Road 1, Smithville, Texas 78957, USA

\begin{abstract}
Using a highly specific radioimmunoassay, the sunlight-induced formation of cyclobutane pyrimidine dimers (CPDs) and pyrimidine (6-4) pyrimidone photoproducts ([6-4] PPs) in viral DNA was investigated for natural virus communities in offshore and coastal waters of the western Gulf of Mexico as well as for clonal viral isolates. Concentrations of (6-4) PPs were consistently lower than CPD concentrations, and ranged from 1.5 to $17.0 \%$ of total measured photodamage. The accumulation of photoproducts varied among the natural viral community, the marine Vibrio phage PWH3a-P1 and the Synechococcus sp. DC2 (WH7803) cyanophage SYN-M3, which were deployed in situ from dawn until dark. Natural viral communities were more resistant to DNA damage than the cyanophage isolate SYN-M3. which was more resistant to damage than bacteriophage PWH3a-P1. Moreover, depth profiles revealed that photodamage in viral isolates deployed in the water column accumulated more rapidly at offshore stations than at coastal stations. In natural virus communities collected from offshore surface waters, photodamage accumulated during the solar day with maximum damage occurring between 15:00 and 18:00 h. Depth profiles obtained during calm seas showed that photodamage concentrations were high in surface waters at the offshore stations and at 1 coastal station. Results at other coastal stations undergoing significant mixing demonstrated no photoproduct accumulations. Results demonstrate that natural virus communities were more tolerant to DNA damaging radiation than the laboratory isolates used in this study. Consequently, laboratory isolates can be poor proxies for UV impacts on natural viral communities.
\end{abstract}

KEY WORDS: Marine viruses - UV - Pyrimidine dimers - 6-4 Photoproducts - DNA damage

\section{INTRODUCTION}

Increases in the biologically harmful ultraviolet $B$ radiation (UV-B; 280 to $320 \mathrm{~nm}$ ) reaching the Earth due to ozone layer degradation (Jones \& Shanklin 1995) have rekindled interest in the biological effects of UV in marine systems (Smith \& Baker 1979, Karentz \& Lutze 1990, Karentz et al. 1994). UV-B can have dele-

\footnotetext{
- Present address: Department of Microbiology, The University of Tennessee, Knoxville, Tennessee 37996-0845, USA

*Addressee for correspondence. E-mail: suttle@eos.ubc.ca
}

terious effects on prokaryotic and eukaryotic primary production (Worrest et al. 1981, Karentz et al. 1991b, Cullen et al. 1992, Behrenfeld et al. 1993, Quesada 1995), as well as prokaryotic secondary production (Bailey et al. 1983, Sieracki \& Sieburth 1986, Herndl et al. 1993, Jeffrey et al. 1996bj. Sunlight can affect pigmentation, motility and carbon uptake in phytoplankton, and amino acid uptake as well as DNA and protein synthesis in bacterioplankton. Moreover, solar radiation is a major cause of the destruction of viral infectivity in surface waters (Suttle \& Chen 1992, Murray \& Jackson 1993, Wommack et al. 1996, Noble \& Fuhrman 
1997. Wilhelm et al. 1998a). While we have gained insight on the biological and biochemical effects of UV exposure for eukaryotes and prokaryotes, information on the impact of UV on natural virus communities remains limited.

The UV radiation that penetrates the surface layers of aquatic systems plays a critical role in the balance of microbial food webs. Increases in UV-B penetration may result in changes in species composition and biogeochemical cycles (Karentz et al. 1994). Since interactions between organisms in pelagic food webs are tightly coupled, UV radiation influences (both positively and negatively) the overall productivity of a system as well as specific trophic levels; indeed, photolysis of recalcitrant organic matter can stimulate bacterial growth (Mopper et al. 1991, Wetzel et al. 1995, Miller \& Moran 1997).

Viral lysis can be as important as flagellate grazing in the mortality of marine bacterial communities (Fuhrman \& Noble 1995, Weinbauer \& Peduzzi 1995, Steward et al. 1996), and may remove a significant proportion of the primary production in nature (Suttle et al. 1990, Suttle 1992, Bratbak et al. 1993, Brussaard et al. 1996). In contrast to the potentially deleterious effects of UV-B on microorganisms, UV-induced destruction of viral infectivity may reduce virallymediated mortality of bacterio- and phytoplankton. In order to evaluate the effect of viruses on primary and secondary production, we therefore require a better understanding of the effect of sunlight on viral infectivity.

UV-B is thought to be the primary component of sunlight that damages biological activities (Sieracki \& Sieburth 1986, Suttle \& Chen 1992, Jeffrey et al. 1996a). The most important types of UV-B induced DNA photodamage appear to be the formation of cyclobutane pyrimidine dimers (CPDs) and pyrimidine (6-4) pyrimidone photoproducts ([6-4] PPs) (Mitchell \& Nairn 1989). Since a single distortion in the DNA may be sufficient to stop DNA transcription (Protic-Sabljic \& Kraemer 1985), DNA damage could be a primary cause for sunlight-induced mortality. Since viruses lack pigmentation and have only a thin protein coat, viral DNA can be subject to severe, sunlight-induced DNA damage.

Information on the concentrations and accumulation rates of sunlight-induced DNA damage in natural microbial communities is limited (Karentz et al. 1991a, Jeffrey et al. 1996a, Wilhelm et al. 1998b). We previously demonstrated that CPDs accumulated in natural virus communities from surface waters during the solar day, and that the process of photoreactivation could restore more infectivity in marine viruses than lightindependent repair processes alone (Weinbauer et al. 1997, Wilhelm et al. 1998b). In studies conducted in oligotrophic waters in the Gulf of Mexico, CPDs accumulated during the solar day in bacterio- and phytoplankton in calm seas, whereas wave action and mixing strongly reduced the formation of CPDs. Moreover, CPD concentrations were higher in bacterial DNA than in phytoplankton DNA (Jeffrey et al. 1996a,b). Here we present a more comprehensive investigation of the accumulation of CPDs as well as (6-4) PPs in marine phage isolates deployed in situ, as well as in natural virus communities in the mixed layer in offshore and coastal waters of the Gulf of Mexico.

\section{MATERIAL AND METHODS}

Study sites and sampling. Water samples were collected during cloudless days along a transect in the Gulf of Mexico from June 20 to 28, 1995 (Stn B: $25^{\circ}$ $19^{\prime} \mathrm{N}, 94^{\circ} 07^{\prime} \mathrm{W}$; $\operatorname{Stn} \mathrm{C}: 25^{\circ} 41^{\prime} \mathrm{N}, 94^{\circ} 26^{\prime} \mathrm{W}$; Stn E: $27^{\circ}$ $00^{\prime} \mathrm{N}, 96^{\circ} 14^{\prime} \mathrm{W}$; Stn F: $27^{\circ} 32^{\prime} \mathrm{N}, 96^{\circ} 45^{\prime} \mathrm{W}$ ) and during a partially cloudy day on November 1, 1995 (Stn J: $27^{\circ} 32^{\prime} \mathrm{N}, 96^{\circ} 12^{\prime} \mathrm{W}$ ). Seawater was collected with a submersible pump or 301 Niskin bottles mounted on a rosette. Chlorophyll a (chl a) concentrations were determined fluorometrically as described in Parsons et al. (1984). The attenuation of UV-B radiation $(305 \mathrm{~nm})$ in the water column was determined daily at $12: 00 \mathrm{~h}$ with a Biospherical PUV-500 profiling radiometer. Mixing depths were inferred from multiple temperature and salinity profiles obtained with a Sea Bird CTD (model SBE plus).

Preparation of phage isolates. Bacteriophage PWH3a-P1 (subsequently referred to as PWH3a-P1) and the cyanophage SYN-M3 (subsequently referred to as M3) were amplified, respectively, using the marine bacterium Vibrio sp. (Strain PWH3a) and the cyanobacterium using Synechococcus sp. DC2 (= WH7803) as hosts (Suttle \& Chen 1992, Suttle \& Chan 1993). Viruses were added to exponentially growing hosts at a ratio of ca 0.1 infectious viruses per host cell. Infectivity was measured by plaque assay for PWH3aP1 (Suttle \& Chen 1992) and by MPN assay for M3 (Suttle \& Chan 1993). After all host cells had lysed (ca 12 to $24 \mathrm{~h}$ ), cellular debris was separated from the phages by centrifugation and subsequent filtration through $0.22 \mu \mathrm{m}$ pore size low protein binding filters (Durapore). For cyanophages, the viruses were concentrated from $10 \mathrm{l}$ lysates to ca $1 \mathrm{l}$ using ultrafiltration (Suttle et al. 1991) (Amicon S1Y30 cartridge; 30000 MW cutoff). Isolates were stored in the dark at $4{ }^{\circ} \mathrm{C}$ until use.

In situ deployments. Aliquots of filtered lysate $(50 \mathrm{ml})$, containing about $10^{12}$ infectious bacteriophage or $10^{10}$ infectious cyanophages, were transferred and sealed into UV-transparent polyethylene bags (Fisher- 
brand; light transmission, $88 \%$ at $305 \mathrm{~nm}, 91 \%$ at $320 \mathrm{~nm}$ ). These concentrations of viruses were estimated to provide sufficient amounts of DNA for analysis (below). The samples were attached to a series of PVC racks and suspended at fixed depths $(1,5,10$, $15 \mathrm{~m}$ ) by a free-floating buoy along a line that supported $20 \mathrm{~kg}$ of ballast at the bottom (Karentz \& Lutze 1990). In addition, a rack was provided with independent floats and attached to the buoy with $5 \mathrm{~m}$ of nylon rope. Samples were exposed to sunlight for the duration of the solar day (12 h). Dark controls were maintained at in situ temperatures in a flowing seawater bath. Samples were replicated by the deployment of independent duplicate buoys. Rough seas prevented deployments at Stn J.

The in situ concentration of photoproducts in the DNA of natural virus communities was determined in 100 l samples of seawater that were collected between 03:00 and 18:00 $\mathrm{h}$ from surface waters, and between 16:00 and 19:00 $\mathrm{h}$ for depth profiles. Samples were serially filtered through $1.2 \mu \mathrm{m}$ nominal pore size glass fiber filters (147 mm diameter; Gelman GC50) and a $0.2 \mu \mathrm{m}$ pore size polycarbonate cartridge filter (Nuclepore) to remove zooplankton, phytoplankton and bacteria. The viruses remaining in the $0.2 \mu \mathrm{m}$ filtrate were concentrated to ca 100 to $500 \mathrm{ml}$ using ultrafiltration (Suttle et al. 1991) (Amicon S10Y30 and S1Y30 cartridges; $30000 \mathrm{MW}$ cutoff).

Concentration efficiencies were determined in DAPI stained samples (Suttle 1993). Samples were taken both pre- and post-filtration. Concentration efficiencies were determined as the percentage of viruses remaining after concentration when corrected for volume changes. Efficiencies in this study ranged from 80 to $100 \%($ mean $=89 \%)$.

The total potential accumulation of DNA photoproducts in the natural viral community was assessed by placing ca $100 \mathrm{ml}$ of the concentrated viral community (collected prior to sunrise) into sample bags and deploying them alongside the viral isolates in on-deck, flowing seawater incubators. At the end of the solar day samples were removed and DNA was extracted as described.

Purification of viral DNA and determination of photodamage. Phage isolates and concentrates of the natural virus communities were heat treated $\left(95^{\circ} \mathrm{C}\right.$, $20 \mathrm{~min}$ ) to release the DNA from the protein capsids. Viral DNA was precipitated with hexadecyltrimethylammonium bromide (CTAB, Sigma Chemical Co. No. $\mathrm{H} 6269$ ) by freezing at $-20^{\circ} \mathrm{C}$ as described in Karl \& Bailiff (1989), and CTAB-DNA salts were collected by centrifugation (Sorvall GSA rotor; $23500 \times g, 2.5 \mathrm{~h}$ ). Viral DNA was further purified with chloroform extraction and precipitated with ethanol (Sambrook et al. 1989). DNA was redissolved in autoclaved deionized- distilled water, and DNA concentrations in subsamples were determined using diaminobenzoic acid (DABA, Sigma Chemical Co. No. D 1891) (Karl \& Bailiff 1989).

CPDs and (6-4) PPs were quantified in viral DNA using a competitive radioimmunoassay (RIA) as described in Mitchell (1996). The antisera were raised against DNA that was either irradiated with UV-C light (100 $\mathrm{kJ} \mathrm{m}^{-2}$ at $254 \mathrm{~nm}$ for [6-4] PPs), or dissolved in $20 \mathrm{mM}$ acetophenone and irradiated with UV-B light under conditions that have been shown to produce thymidine-thymidine CPDs exclusively. For the RIA, 2 to $5 \mu \mathrm{g}$ of heat-denatured DNA was incubated with 5 to $10 \mathrm{pg}$ of poly $(\mathrm{dA}): \operatorname{poly}(\mathrm{dT})$ (labeled to $>5 \times 10^{8} \mathrm{cpm}$ $\mu \mathrm{g}^{-1}$ by nick translation with ${ }^{32} \mathrm{P}-\mathrm{dTTP}$ ) in a total volume of $1 \mathrm{ml}$ buffer (10mM Tris, pH 7.8, $150 \mathrm{mM} \mathrm{NaCl}$, $1 \mathrm{mM}$ EDTA, $0.2 \%$ gelatin [Sigma]) and $20 \mu \mathrm{g} \mathrm{ml}^{-1} \mathrm{sin}-$ gle- and double-stranded (1:1) salmon DNA (Sigma). Antiserum was added to the reaction mixture at a dilution that yielded 30 to $60 \%$ binding of the labeled ligand $\left(5 \times 10^{-5}\right.$ for [6-4] PPs; $10^{-5}$ for CPDs). After incubation overnight at $4^{\circ} \mathrm{C}$, the immune complex was precipitated with goat anti-rabbit immunoglobulin (Calbiochem) and carrier serum from nonimmunized rabbits (Calbiochem). After centrifugation the pellet was dissolved in tissue solubilizer (NCS, Amersham), mixed with acid Scintiverse (Fisher), and the ${ }^{32} \mathrm{P}$ was quantified by liquid scintillation spectrometry. Under these conditions, when antibodies bind to an unlabeled competitor, binding to the radiolabeled ligand is reduced and quantifiable in the precipitate (i.e. \% inhibition). Samples were analyzed in duplicate and the assays standardized with DNA of a known photoproduct concentration. The percentage of a specific damage (either [6-4] PPs or CPDs) as a function of total measurable damage was calculated as

$$
100 \% \times D /[(6-4) P P s+C P D s]
$$

where $D$ represents the concentration of the photoproduct of interest.

\section{RESULTS}

\section{Chl a concentrations, light penetration and mixing depth}

Chl a concentrations integrated over the mixed layer were used to divide the stations into 2 groups. Offshore at Stns B and C, chl a concentrations were $<0.1 \mu \mathrm{gl}^{-1}$, whereas at the coastal Stns E, F, and J, the chl a concentrations were a minimum of 2 -fold higher (Table 1 ). This grouping of the stations correlates to the light penetration data. The depth at which $1 \%$ of the surface $305 \mathrm{~nm}$ light remained was about $24 \mathrm{~m}$ at Stns B and C, and about $2 \mathrm{~m}$ at Stns E and F (Table 1). Stations occu- 
pied in June were completely cloudless, while Stn J (November) experienced significant cloud cover. The mixing depth, estimated from up to 8 salinity and temperature profiles at the different stations, was between 22 and $29 \mathrm{~m}$ at Stns $\mathrm{B}, \mathrm{C}$, and $\mathrm{F}$, and about $10 \mathrm{~m}$ at Stn E.

\section{Photodamage in the phage isolates}

In all deployments, CPD concentrations in the bacteriophage DNA were highest at the surface and decreased with depth (Fig. 1). Offshore at Stns B and C, $\mathrm{CPD}$ concentrations were higher than dark incubations (ca 50 CPDs $\mathrm{Mbp}^{-1}$ DNA) up to $10 \mathrm{~m}$ depth, whereas, nearer the coast at Stns E and F, CPDs were only greater than dark controls at the surface. The concentrations of the (6-4) PPs showed a similar distribution with depth (Fig. 2). At Stns B and C, concentrations of (6-4) PPs were also higher than those in dark incubations (ca $2[6-4]$ PPs $\mathrm{Mbp}^{-1}$ DNA) up to $10 \mathrm{~m}$ depth, whereas, at the coastal Stns E and F, (6-4) PPs were

\section{CPDs / Mb DNA}

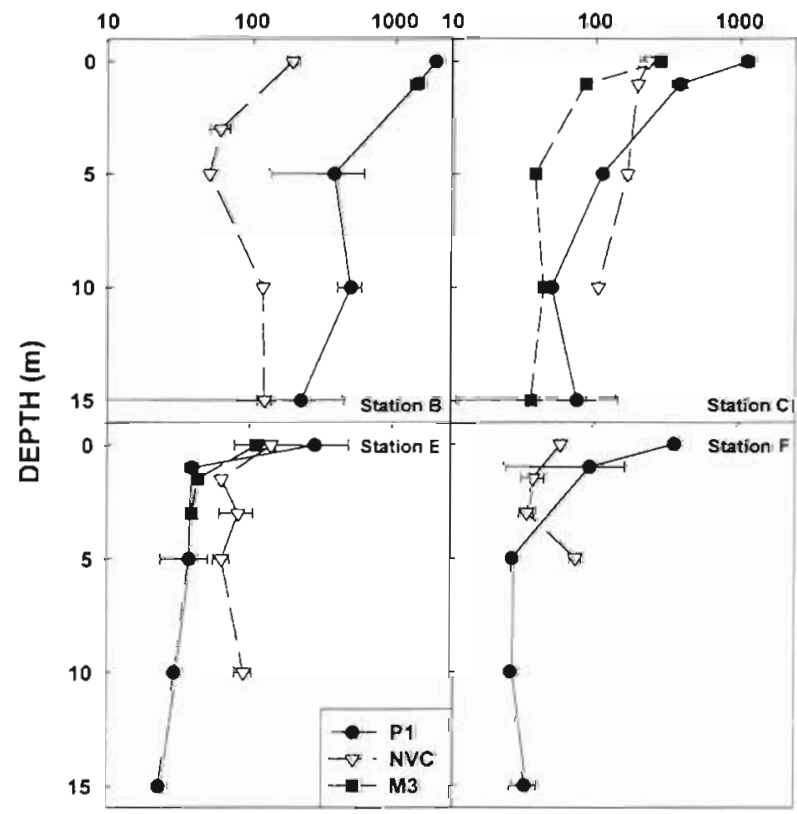

Fig. 1. Depth profiles of cyclobutane pyrimidine dimer (CPD) concentrations in the DNA of phage isolates and natural virus communities. Bacteriophage PWH3a-P1 (P1) and cyanophage SYN-M3 (M3) were deployed for the entire light period, whereas the natural virus community (NVC) was concentrated from specific depths at the end of the solar day. Data for the viral isolates are the means of independent duplicate incubations, while data for the NVC are the means of duplicate measurements from the same sample. When error bars are not shown the range from duplicate incubations or measurements was less than the width of the symbols
Table 1. Mixing depth, light penetration, and chl a concentrations. Light penetration depth is for $305 \mathrm{~nm}$ wavelength. ND: not determined

\begin{tabular}{|lccc|}
\hline Stn & $\begin{array}{c}\text { Mixing depth } \\
(\mathrm{m})\end{array}$ & $\begin{array}{c}\text { 1\% light penetration } \\
\text { depth }(\mathrm{m})\end{array}$ & $\begin{array}{c}\mathrm{Chl} \mathrm{C} \\
\left(\mathrm{\mu g} \mathrm{l}^{-1}\right)\end{array}$ \\
\hline Offshore & & & \\
B & 22.3 & 23.0 & 0.04 \\
C & 26.9 & 24.4 & 0.08 \\
Coastal & & & \\
E & 10.2 & 2.1 & 0.17 \\
F & 28.7 & 2.0 & 0.21 \\
J & ND & ND & 0.35 \\
\hline
\end{tabular}

only detected up to $1 \mathrm{~m}$. This indicates that photodamage concentrations in the DNA of the bacteriophage were higher at the offshore stations than at the more coastal stations.

M3 was only deployed at Stns C and E. CPD and (6-4) PP concentrations in the cyanophage DNA decreased with depth (Fig. 1). At depths of 0 to $1 \mathrm{~m}$ at Stn $\mathrm{C}$, and in surface deployments at Stn E, CPD con-

(6-4) PPs / Mb DNA

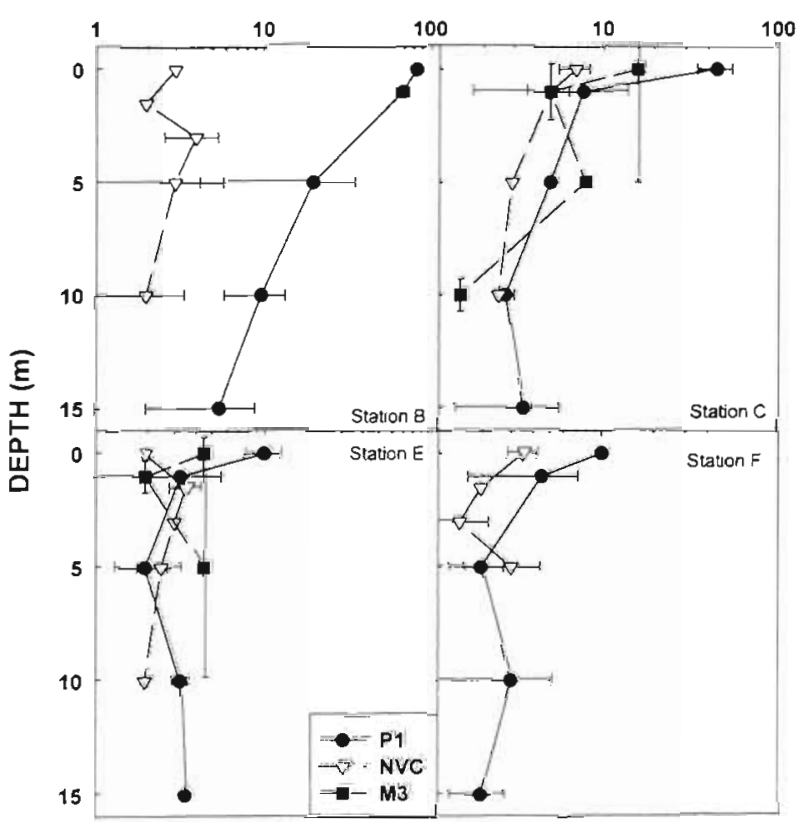

Fig. 2. Depth profiles of pyrimidine (6-4) pyrimidone photoproduct ([6-4] PP) concentrations in the DNA of phage isolates and natural virus communities. Bacteriophage PWH3a-P1 and cyanophage M3 were deployed for the entire light period, whereas the natural virus community (NVC) was concentrated from specific depths at the end of the solar day. Data for the isolates are the means of duplicate incubations and data for the NVC are the means of 2 measurements from the same sample. When error bars are not shown the range was less than the width of the symbols 
centrations were higher than those in dark incubations. Detectable (6-4) PP concentrations were found at up to $5 \mathrm{~m}$ depth at Stn $\mathrm{C}$, but only in surface water at Stn E (Fig. 2). This indicates that photodamage concentrations in the DNA of the cyanophage were higher offshore at Stn C than at the more coastal Stn E. At both stations, CPD and (6-4) PP concentrations in M3 were significantly lower (2-tailed paired $t$-test; $\mathrm{p}<$ 0.05) than in PWH3a-P1.

The concentrations of CPDs in the DNA of PWH3aP1 were significantly correlated $(r=0.982 ; \mathrm{p}<0.001$; $\mathrm{n}$ =24) with the (6-4) PP concentrations (Fig. 3). For M3 there was a similar correlation between CPD and (6-4) PP concentrations ( $r=0.867 ; \mathrm{p}<0.001 ; \mathrm{n}=8$ ) (data not shown). The percentage of the (6-4) PPs relative to the total measurable photodamage in the bacteriophage DNA averaged $5.2 \pm 2.8$ (range, 1.9 to $12.7 ; \mathrm{n}=20$ ) and was not significantly different (2-tailed paired $t$-test, $\mathrm{p}>0.1$ ) from the cyanophage which averaged $5.8 \pm 5.1$ (range, 2.2 to $17.0, \mathrm{n}=8$ ).

\section{Photodamage in the natural virus communities}

The concentration of CPDs and (6-4) PP in the DNA of viruses collected before sunrise were not significantly different (2-tailed paired $t$-test; $\mathrm{p}>0.4$ and $\mathrm{p}>$ 0.05 , respectively) from those of bacteriophages incubated in the dark. This indicates that there was no measurable damage (beyond background levels) in the natural virus communities collected before sunrise.

Samples for CPDs in the DNA of natural virus communities were collected from surface water $(0.5 \mathrm{~m})$ between 03:00 and 18:00 h (Fig. 4). At the oligotrophic Stns $B$ and $C, C P D$ concentrations generally increased during the day; the highest CPD concentrations were found between 15:00 and 18:00 h. In coastal waters the dimer formation was less. At Stn E, there was some dimer formation at noon, whereas at Stn F, the CPD concentrations were close to the detection limit. At Stns B and E, samples were also collected ca $24 \mathrm{~h}$ after the first sampling, i.e. immediately before sunrise the following day. CPD concentrations were close to those in dark incubations of PWH3a-P1, indicating that the damage was removed during the night. The (6-4) PP concentrations in samples collected from surface water between 03:00 and 18:00 h (Fig. 4) showed a trend comparable to that found for CPDs. At Stns B and E, samples were also collected about $27 \mathrm{~h}$ after the first sampling, and (6-4) PP concentrations did not differ from those in dark incubations of PWH3a-P1.

Samples from depth profiles for CPD and (6-4) PP concentrations in the DNA of natural virus communities were collected between 15:00 and 19:00 h (Figs. 1 \& 2). At Stns B, C and E the highest CPD concentra-

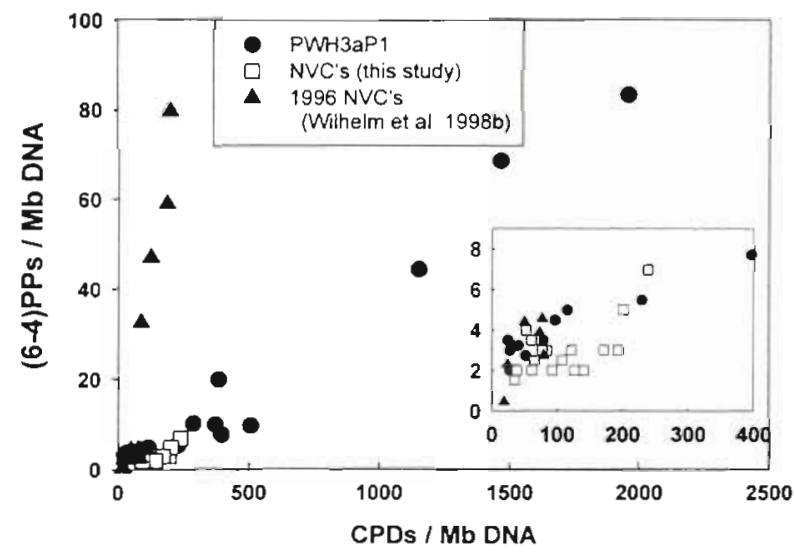

Fig. 3. Relationship between CPD and (6-4) PP concentrations in the DNA of the natural virus community, the bacteriophage PWH3a-P1 and the cyanophage M3. Natural virus community data are presented from this study as well as from Wilhelm et al. (1998b). The insert is a close up of the data for the natural virus community from this study

tions were found in surface water. At Stns $C$ and $E$, the $\mathrm{CPD}$ concentrations decreased with depth. However, at $\operatorname{Stn} B$, the CPD concentrations at 10 and $15 \mathrm{~m}$ were

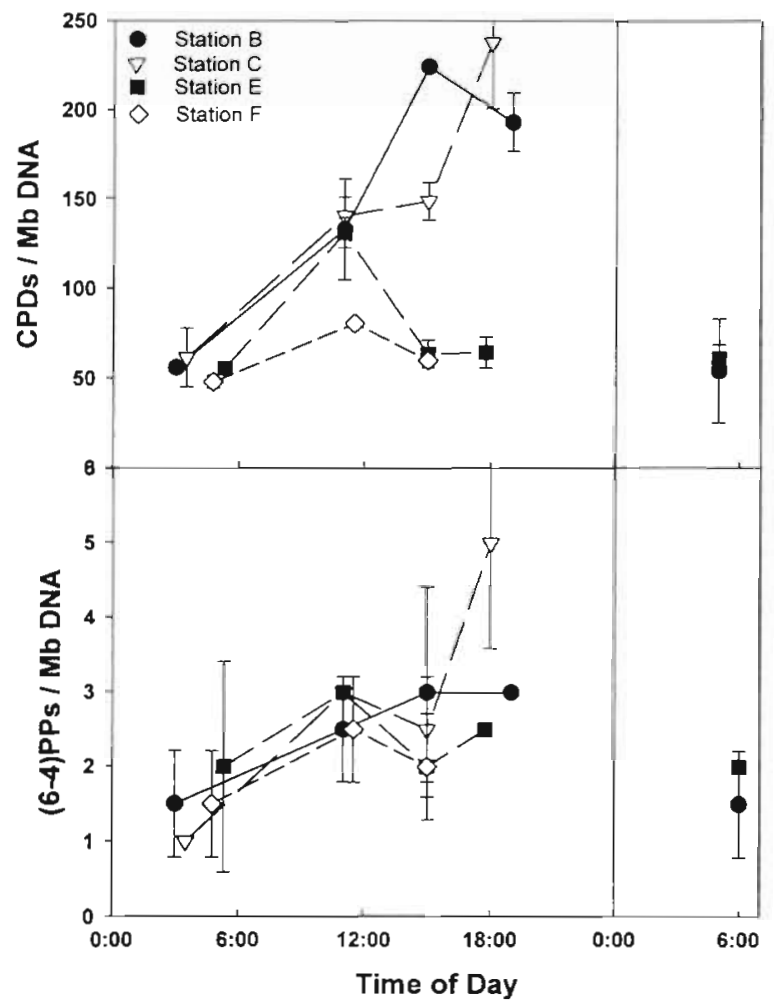

Fig. 4. Diel pattern of CPD and (6-4) PP accumulation in the DNA of natural virus communities in surface waters $(0.5 \mathrm{~m})$. When error bars are not shown the range of error was less than the width of the symbols. The second samples from Stns $B$ and $E$ (at $06: 00 \mathrm{~h}$ ) are from the subsequent morning 
Table 2. Photodamage (per Mb DNA) accumulation in the DNA of natural virus communities. At Stn J the values were averaged from samples collected at the surface and $0.5 \mathrm{~m}$

\begin{tabular}{|c|c|c|c|}
\hline \multirow[t]{2}{*}{ Stn } & \multicolumn{2}{|c|}{$\begin{array}{c}\text { Integrated photodamage } \\
\text { in natural virus } \\
\text { communities }\end{array}$} & \multirow{2}{*}{$\begin{array}{c}\text { Photodamage in natural virus } \\
\text { communities concentrates } \\
\text { exposed at the surface } \\
\text { CPDs }\end{array}$} \\
\hline & CPDs & $(6-4)$ PPs & \\
\hline B & 87.9 & 2.6 & $45(2.12)$ \\
\hline $\mathrm{C}$ & 97.8 & 2.8 & $47.5(2.12)$ \\
\hline$E$ & 78.9 & 2.6 & $51.0(15.6)$ \\
\hline $\mathrm{F}$ & 49.0 & 2.1 & $47.5(3.5)$ \\
\hline$J$ & 49.5 & 2.0 & ND \\
\hline
\end{tabular}

more than 2-fold higher than at 3 and $5 \mathrm{~m}$. The $\mathrm{CPD}$ concentrations at Stn F did not differ from those in dark incubations of PWH3a-P1 or in natural virus communities collected in the morning at Stns B and E. At Stn J, we did not find a significant amount of CPD formation in viruses collected from 0.5 and $5 \mathrm{~m}$ (data not shown). At Stn C the (6-4) PP concentrations decreased with depth (Fig. 2), whereas at the other stations almost no (6-4) PPs were detected.

To estimate the net accumulation of CPDs in the DNA of natural virus communities during the solar day, photodamage was integrated over the mixed layer assuming that photodamage concentrations in the waters below the deepest sampling point were not different from those in dark incubations of PWH3a-P1. We estimated that between 78.9 and $97.8 \mathrm{CPDs} \mathrm{Mbp}^{-1}$ DNA accumulated in the mixed layer at Stns B, C and $E$, whereas at Stns $F$ and $J$ the CPD concentrations (Table 2) were not different from those collected before sunrise, or those obtained in dark incubations of PWH3a-P1. These values, however, were higher than those measured for viral concentrates deployed over the solar day in on-deck incubators.

The percentage of (6-4) PPs relative to the total measurable photodamage concentration in the DNA of natural virus communities was $3.1 \pm \mathrm{SD}=1.5$ (range, 1.5 to 9.0; $\mathrm{n}=37$ ). The percentage of (6-4) PPs in natural virus communities was significantly (2-tailed paired $t$-test, $p<0.001)$ lower than that in PWH3a-P1 and M3. The $\mathrm{CPD}$ concentrations in the natural virus communities were correlated significantly $(\mathrm{r}=0.705 ; \mathrm{p}<0.001 ; \mathrm{n}=$ 37) with the (6-4) PP concentrations (Fig. 3).

\section{DISCUSSION}

This study provides quantitative information on sunlight-induced DNA damage in natural virus communities. In the mixed layer of oceanic waters photodamage accumulated during the solar day in natural virus communities. Photodamage can also accumulate in the mixed layer of more turbid coastal waters if the mixing depth is shallow and the sea is calm. However, wave action and mixing can prevent the accumulation of photodamage. The results are significant as they demonstrate that viral isolates may not be good proxies for all of the biological effects of UV radiation in the natural virus community, since the viral isolates accumulated DNA photoproducts more readily than natural virus communities.

\section{Concentrations and types of photodamage}

On average, (6-4) PP concentrations accounted for $5 \%$ of the total measurable photodamage in the DNA of bacteriophages, cyanophages and natural virus communities. Therefore, on average more than $90 \%$ of the measured photodamage was due to CPD formation. However, since (6-4) PPs have a stronger deleterious effect on DNA transcription than CPDs (Mitchell \& Nairn 1989), they might cause significant losses of viral infectivity. Further to this, since the repair of (6-4) PPs by host-cell excision mechanisms is error prone (in comparison to the error-free reversion of CPDs by photolyase), the (6-4) PPs may also lead to point mutations in the genome (Friedberg et al. 1995).

The correlation between CPD and (6-4) PP concentrations was strong for isolates relative to the natural virus communities (Fig. 3). The weak correlation in the natural virus communities might be a result of the noise in the (6-4) PP measurements at lower levels of photodamage, since the (6-4) PP concentrations were often close to the background concentration. During this study the highest (6-4) PP concentration in the DNA of natural virus communities was $5 \mathrm{Mbp}^{-1}$ compared to the background concentration of about 2 $\mathrm{Mbp}^{-1}$ obtained in dark incubations with PWH3a-P1. Results from 3 stations in 1996 showed higher levels of (6-4) PP, and a stronger correlation to CPDs (Fig. 3). However, all the data demonstrate a definite difference between the isolates and natural community in the accumulation of the different types of photodamage.

Since the ratio of (6-4) PPs to CPDs depends on the DNA sequence (Bourre et al. 1987), the high diversity of viruses which is probably present in seawater may affect the relationship between (6-4) PPs and CPDs. Moreover, damaged natural virus communities may be transported into deeper water by mixing, whereas the phage isolates were deployed at fixed depths. Longer wavelengths result in the photoisomerization of the (6-4) PP to the Dewar isomer (Mitchell \& Nairn 1989, Friedberg et al. 1995), which is not measured by our method. While there is limited information concerning the effect of Dewar isomers on viral infectivity, it seems 
likely that this form of DNA damage is as disruptive to the infectivity of viruses as (6-4) PPs. Since longer wavelengths of light are attenuated less in the water column, damaged viruses may be mixed to depths where no further damage occurs, but (6-4) PPs can still be converted to the Dewar photoproduct. The exposure of the natural communities to longer wavelengths therefore suggests that our estimates for the formation of (6-4) PPs in situ are minimum estimates. Finally, the natural virus communities remained in the presence of host cells for the duration of these experiments, so the processes of photoreactivation, excision repair and viral production will all affect this relationship (Weinbauer et al. 1997, Wilhelm et al. 1998a,b). In all, the natural processes may result in the weaker correlation between CPDs and (6-4) PPs, as well as in the lower percentage of (6-4) PPs in natural virus communities compared to phage isolates.

\section{Differences in photodamage between viral isolates}

At Stns C and E, M3 was deployed in parallel with PWH3a-P1. Photodamage concentrations were significantly lower in the cyanophage than in the bacteriophage, indicating that the DNA of M3 is more resistant to sunlight-induced damage than that of PWH3a-P1. The most reasonable explanation for this is that variations in the DNA confer a greater resistance to UV damage in M3. This resistance to DNA damage may be the reason why the solar-radiation-mediated decay rates of viral infectivity are lower in $\mathrm{M} 3$ than in PWH3a-P1 (Garza \& Suttle 1998, Wilhelm et al. 1998a). However, light dependent-repair, i.e. photoreactivation, might be a reason for the lower estimated decay rates of cyanophages relative to bacteriophages, since host cells are grown in visible light during phage titration and photolyase is induced by wavelengths between 300 and $500 \mathrm{~nm}$ (Friedberg et al. 1995). However, Garza \& Suttle (1998) also found that the infectivity of natural cyanophage communities in the summer was more resistant to damage from solar radiation than cyanophage isolates, including M3. Studies have also shown that different phages loose infectivity at different rates under the same irradiance (Suttle \& Chen 1992, Wommack et al. 1996, Noble \& Fuhrman 1997. Wilhelm et al. 1998b).

\section{Photodamage in natural virus communities}

Depth profiles showed that the highest concentrations of photodamage occurred at the surface (Figs. 1 \& 2 ), and that damage generally increased during the solar day at the surface (Fig. 4). At the offshore stations the highest CPD concentrations were found between 15:00 and 18:00 h, similar to findings for bacterioplankton (Jeffrey et al. 1996b). In the current study the maximum rate of photodamage accumulation in surface waters was $29.7 \mathrm{CPDs} \mathrm{Mbp}^{-1} \mathrm{~h}^{-1}$ and less than 1 (6-4) $\mathrm{PP} \mathrm{Mbp}^{-1} \mathrm{~h}^{-1}$. In bacterioplankton CPDs accumulated at a rate of $110 \mathrm{Mbp}^{-1} \mathrm{~h}^{-1}$ (Jeffrey et al. 1996b) The reasons for the lower photodamage accumulation rates in viro- than in bacterioplankton are unknown. Light-dependent repair by host cells is very efficient in restoring infectivity to sunlight- and UV-damaged viruses (Weinbauer et al. 1997), and, therefore, might slow down the net accumulation rate of photodamage. However, one would expect that the host community would be as efficient at repairing its own damaged DNA. Virus replication leads to the production of a high number (ca 20 to 100) of undamaged viral progeny that greatly dilutes the concentration of DNA photoproducts in the viral size fraction; the same is not true for bacteria.

Solar-radiation-induced lysogenic phage production may also be important for diluting photodamage, since it would occur simultaneously with damage. However, there is evidence from various environments (Bratbak et al. 1994, Wilcox \& Fuhrman 1994, Jiang \& Paul 1996) including the investigated stations (Weinbauer \& Suttle 1996) that solar radiation does not cause a significant increase in viral abundances as a result of the induction of lysogens. We also found that samples collected in the morning showed photodamage that was not higher than the concentrations in PWH3a-P1 incubated in the dark (about 50 CPDs $\mathrm{Mbp}^{-1}$ ). Thus, the damage that accumulated in viroplankton DNA during the day was removed or diluted during the night. In contrast, bacterioplankton collected in the morning showed residual CPD concentrations of about $200 \mathrm{Mbp}^{-1}$ (Jeffrey et al. 1996a).

- The deployment of concentrated natural virus communities under full sunlight for the entire solar day demonstrates the resistance of the natural virus communities to UV-mediated DNA damage. The concentration of CPDs in samples exposed to a complete solar day ranged from ca 45 to 51 photoproducts $\mathrm{Mb}^{-1}$ DNA (Table 2). Similarly, (6-4) PP concentrations were also near background levels (data not shown). While this may be the result of some attenuation by the sample bags, these amounts of photodamage are still significantly less than the amount of photoproduct accumulated by the isolates deployed in surface waters.

The UV radiation penetrated deeper at the offshore stations relative to the coastal stations (Table 1). The differences in light penetration among stations are also reflected in the photodamage concentrations of the deployed phages (Figs. 1 \& 2). However, when photodamage in the natural virus community was integrated 
over the mixed layer, the photodamage at coastal Stn E was comparable to that offshore at Stns B and C (Table 2), since the mixing depth at Stn $E$ was only $10 \mathrm{~m}$ (compared to more than $20 \mathrm{~m}$ at the other stations). This demonstrates that sunlight can cause significant damage in virus DNA in less transparent waters when the mixing depth is shallow. At Stn F, where the light penetration depth was comparable to that at Str E, there was almost no CPD formation, and at Stn $J$ we did not find CPD or (6-4) PP concentrations in the natural virus communities that were higher than those in dark incubations of PWH3a-P1 (Figs. 1 \& 2). At Stns $B, C$ and $E$ the sea was calm, whereas at Stns $F$ and $J$ the sea was moderate to rough. This suggests that higher mixing rates of the water column prevent photodamage accumulation in viral DNA. Mixing also prevented the formation of CPDs in bacterioplankton (Jeffrey et al. 1996a,b). Thus, mixing depth and rates have to be considered when the effect of solar radiation on aquatic microorganisms is investigated.

When the sea is calm, it would be expected that DNA damage in natural virus communities would accumulate during the day, and the rate of accumulation decreases with depth. Although photodamage generally increased during the day at the surface (Fig. 4), there was no continuous decrease of photodamage with depth at Stns B and E (Figs. 1 \& 2). For example, at Stn B the formation of CPDs at $15 \mathrm{~m}$ in the natural viral community was higher than in dark incubations of PWH3a-P1, whereas CPDs were not detectable in the deployed bacteriophages. A variety of dosimeters, such as DNA-repair-deficient bacterial strains (Karentz \& Lutze 1990, Puskeppeleit et al. 1992), naked DNA (Regan et al. 1992, Jeffrey et al. 1996b) and bacteriophage infectivity (Rontó et al. 1994, Wilhelm et al. 1998a) have been used to monitor the penetration of UV radiation into the water column. In addition, the accumulation of photodamage in the deployed phages is a direct result of damaging wavelengths penetrating into the water. Thus, our finding that photodamage formation in the deployed bacteriophages strongly differs from that in the natural virus community shows that the measurement of UV radiation in the water column, or the use of dosimeters, is not always sufficient to predict the effect of solar radiation on biological activities on time scales where mixing is possible. This supports the finding of Jeffrey et al. (1996b) that the accumulation of photodamage in bacterioplankton can differ from that in. DNA dosimeters.

Although we did not find an accumulation of photodamage at Stns F and J, this does not mean that sunlight had no effect on viral infectivity. Since only a single distortion of DNA might be sufficient to stop DNA replication (Protic-Sabljic \& Kraemer 1985), a small amount of damage that is not detectable by our method could still cause losses of infectivity. Moreover, losses of viral infectivity might be replaced simultaneously by repair or new virus production without an accumulation of photodamage.

Overall, while our data support earlier findings based on isolates (Suttle \& Chen 1992, Suttle \& Chan 1994, Wommack et al. 1996, Wilhelm et al. 1998a), natural virus communities (Garza \& Suttle 1998, Wilhelm et al. 1998a,b) and models (Murray \& Jackson 1993) that solar radiation can be a major cause for the destruction of infectivity in natural virus communities in the surface layer of the ocean, it leaves the role of other processes in the regulation of viral abundance open to interpretation (Noble \& Fuhrman 1997, Wilhelm et al. 1998a). The types of viruses present in natural waters, the penetration depth of damaging wavelengths, as well as the mixing depth and mixing rate were identified as the most important factors in the accumulation of photodamage in viruses and sunlightinduced losses of viral infectivity in the Gulf of Mexico. Increased UV-B radiation in the upper layer of the ocean due to the depletion of the ozone layer might result in higher loss rates of viral infectivity. This may decrease the virus-induced mortality of bacteria and phytoplankton and thus potentially counterbalance the deleterious effects of UV-B radiation on microorganisms in the ocean. However, with all the potential feedback loops that exist in microbial food webs, further research on the dynamics of marine viruses will be required to resolve these issues.

Acknowledgements. We thank the captain and the crew of the RV 'Longhorn' for assistance in collecting water samples and W. H. Jeffrey for light data. The help of A. M. Chan, D. R. Garza, K. M. Rodda, R. Sanchez and S. M. Short was greatly appreciated. This research was supported by grants from the National Science Foundation (OCE-9415602) and the Office of Naval Research (N00014-92-5-1676) to C.A.S., and a Erwin-Schrödinger Postdoctoral Fellowship (J00991-BIO) to M.G.W. from the Austrian Science Foundation. National Water Research Institute Contribution no. 98-75 (SWW)

\section{LITERATURE CITED}

Bailey CA, Neihof RA, Tabor PS (1983) Inhibitory effect of solar radiation on amino acid uptake in Chesapeake Bay bacteria. Appl Environ Microbiol 46:44-49

Behrenfeld M, Hardy J, Gucinski H, Hanneman A, Lee $H$, Wones A (1993) Effects of ultraviolet-B radiation on primary production along latitudinal transects in the South Pacific Ocean. Mar Environ Res 35:349-363

Bourre F, Renault G, Sarasin A (1987) Sequence effect on alkali-sensitive sites in UV-irradiated SV40 DNA. Nucleic A.cids Res 15:8861-8875

Bratbak G, Egge JK, Heldal M (1993) Viral mortality of the marine alga Emiliania huxleyi (Haptophyceae) and termination of algal blooms. Mar Ecol Prog Ser 93:39-48

Bratbak $G$, Thingstad F, Heldal M (1994) Viruses and the microbial loop. Microb Ecol 28:209-221 
Brussaard CPD, Kempers RS, Kop AJ, Riegman R, Heldal M (1996) Virus-like particles in a summer bloom of Emiliania huxleyi in the North Sea. Aquat Microb Ecol 10: 105-113

Cullen JC, Neale PJ, Lesser MP (1992) Biological weighting function for the inhibition of phytoplankton photosynthesis by ultraviolet radiation. Science 258:646-650

Friedberg EC, Walker GC, Siede W (1995) DNA repair and mutagenesis. ASM Press, Washington

Fuhrman JA, Noble RT (1995) Viruses and protists cause similar bacterial mortality in coastal seawater. Limnol Oceanogr 40:1236-1242

Fuhrman JA, Suttle CA (1993) Viruses in marine planktonic systems. Oceanography 6.51-63

Garza DR, Suttle CA (1998) The effect of cyanophages on the mortality of Synechococcus spp. and selection for UV resistant viral communities. Microb Ecol 36:281-292

Herndl GH, Müller-Niklas G, Frick J (1993) Major role of ultraviolet- $B$ in controlling bacterioplankton growth in the surface layer of the acean. Nature 362:717-719

Jeffrey WH, Aas P, Lyons MM, Coffin RB, Pledger RJ, Mitchell DL (1996a) Ambient solar radiation-induced photodamage in marine bacterioplankton. Photochem Photobiol 64:419-427

Jeffrey $W H$, Pledger RJ, Aas $P$, Hager $S$, Coffin RB, von Haven R, Mitchell DL (1996b) Diel and depth profiles of DNA photodamage in bacterioplankton exposed to ambient solar ultraviolet radiation. Mar Ecol Prog Ser 137: $283-291$

Jiang SC, Paul JH (1996) Occurrence of lysogenic bacteria in marine microbial communities as determined by prophage induction. Mar Ecol Prog Ser 142:27-38

Jones AE, Shanklin JD (1995) Continued decline of total ozone over Halley, Antarctica, since 1985. Nature 376:409-411

Karentz D, Lutze LH (1990) Evaluation of biologically harmful ultraviolet radiation in Antarctica with a biological dosimeter designed for aquatic environments. Limnol Oceanogr 35:549-561

Karentz D, Cleaver IE, Mitchell DL (1991a) Ultraviolet photobiology of Antarctic Bacillariophyceae (diatoms): molecular and biological responses to UV-B radiation. J Phycol $27: 326-341$

Karentz D. Cleaver IE, Mitchell DL (1991b) Cell survival characteristics and molecular responses of Antarctic phytoplankton to ultraviolet-B radiation. J Phycol 27: 326-341

Karentz D, Bothwell ML, Coffin RB, Hanson A, Herndl GJ, Kilham SS, Lesser MP, Lindell M, Moeller RE, Morrís DP, Neale PJ, Sanders RW, Weiler CS, Wetzel RG (1994) Impact of UV-B radiation on pelagic freshwater ecosystems: report of working group on bacteria and phytoplankton. Arch Hydrobiol Beih 43:31-69

Karl DM, Bailiff MD (1989) The measurement and distribution of dissolved nucleic acids in aquatic environments. Limnol Oceanogr 34:543-558

Miller WL, Moran MA (1997) Interaction of photochemical and microbial processes in the degradation of refractory dissolved organic matter from a coastal marine environment. Limnol Oceanogr 42:1317-1324

Mitchell DL (1996) Radioimmunoassay of DNA damaged by ultraviolet light. In: Pfeiffer G (ed) Technologies for DNA damage and mutations. Plenum Publishing Corp, New York, p 73-83

Mitchell DL, Nairn RS (1989) The biology of the (6-4) photoproduct. Photochem Photobiol 49:805-819

Mopper K, Zhou X, Kieber RJ, Kieber DJ, Sikorski RJ, Jones RD (1991) Photochemical degradation of dissolved organic carbon and its impact on the oceanic carbon cycle. Nature 353:60-62

Murray AG, Jackson GA (1993) Viral dynamics II: a model of the interaction of ultraviolet light and mixing processes on virus survival in seawater. Mar Ecol Prog Ser 102: $105-114$

Noble RT, Fuhrman JA (1997) Virus decay and its cause in coastal waters. A.ppl Environ Microbiol 63:77-83

Parsons T, Maita Y, Lalli C (1984) A manual of chemical and biological methods for seawater analysis. Pergamon Press, Oxford

Protic-Sabljic M. Kraemer KH (1985) One pyrimidine dimer inactivates expression of a transfected gene in Xeroderma pigmentosum cells. Proc Natl Acad Sci (USA) 83: 6622-6626

Puskeppeleit M, Quintern L, el Naggar S, Schott JU, Eschweiler U, Horneck G, Bucker H (1992) Long-term dosimetry of solar radiation in Antarctica with spores of Bacillus subtilis. Appl Environ Microbiol 58:235-2359

Quesada A (1995) Growth of Antarctic cyanobacteria under ultraviolet radiation: UVA counteracts UVB inhibition. J Phycol 31:242-248

Regan JD, Carrier WL, Gucinski H, Olla BL, Yoshida $H$, Fujimura RK, Wicklund RI (1992) DNA as a solar dosimeter in the ocean. Photochem Photobiol 56:35-42

Rontó G, Gáspár S, Gróf P, Bérces A, Gugolya Z (1994) Ultraviolet dosimetry in outdoor measurements based on bacteriophage T7 as a biosensor. Photochem Photobiol 59: $209-214$

Sambrook J, Fritsch EF, Maniatis T (1989) Molecular cloning: a laboratory manual. Cold Spring Harbor Laboratory Press, Cold Spring Harbor, NY

Sieracki ME, Sieburth JM (1986) Sunlight-induced growth delay of planktonic marine bacteria in filtered seawater. Mar Ecol Prog Ser 33:19-27

Smith RC, Baker KS (1979) Penetration of UV-B and biologically effective dose-rates in natural waters. Photochem Photobiol 29:311-323

Steward FG, Smith DC, Azam F (1996) Abundance and production of bacteria and viruses in the Bering and Chukchi Sea. Mar Ecol Prog Ser 131:287-300

Suttle CA (1992) Inhibition of photosynthesis in phytoplankton by the submicron size fraction concentrated from seawater. Mar Ecol Prog Ser 87:105-112

Suttle CA (1993) Enumeration and isolation of viruses In: Kemp PF, Sherr BF, Sherr EB, Cole JJ (eds) Handbook of methods in aquatic microbial ecology. Lewis, Boca Raton, FL, p 121-134

Suttle CA. Chan AM (1993) Marine cyanophages infecting oceanic and coastal strains of Synechococcus: abundance, morphology, cross-infectivity and growth characteristics. Mar Ecol Prog Ser 92:99-109

Suttle CA, Chan AM (1994) Dynamics and distribution of cyanophages and their effect on marine Synechococcus spp. Appl Environ Microbiol 60:3167-3174

Suttle CA, Chen F (1992) Mechanisms and rates of decay of marine viruses in seawater. Appl Environ Microbiol 58: $3721-3729$

Suttle CA, Chan AM, Cottrell MT (1990) Infection of phytoplankton by viruses and reduction of primary productivity. Nature 347:467-469

Suttle CA, Chan AM, Cottrell MT (1991) Use of ultrafiltration to isolate viruses from seawater which are pathogens of marine phytoplankton. Appl Environ Microbiol 57: $721-726$

Weinbauer MG, Peduzzi P (1995) Significance of viruses versus heterotrophic nanoflagellates for controlling bacterial 
abundance in the Northern Adriatic Sea. J Plankton Res 17:1851-1856

Weinbauer MG, Suttle CA (1996) Potential significance of lysogeny to bacteriophage production and bacterial mortality in coastal waters of the Gulf of Mexico. Appl Environ Microbiol 62:4374-4380

Weinbauer MG, Wilhelm SW, Suttle CA, Garza DR (1997) Light-dependent repair restores infectivity to natural marine viral communities and maintains high concentrations of viruses in the sea. Appl Environ Microbiol 63:2200-2205

Wetzel RG, Hatcher PG, Bianchi TS (1995) Natural photolysis by ultraviolet irradiance of recalcitrant dissolved organic matter to simple substrates for rapid bacterial metabolism. Limnol Oceanogr 40:1369-1390

Wilcox RM, Fuhrman JA (1994) Bacterial viruses in coastal

Editorial responsibility: David Karl,

Honolulu, Hawaii, USA seawater: lytic rather than lysogenic production. Mar Ecol Prog Ser 114:35-45

Wilhelm SW, Weinbauer MG, Suttle CA, Jeffrey WH (1998a) The role of sunlight in the removal and repair of viruses in the sea. Limnol Oceanogr 43:586-592

Wilhelm SW, Weinbauer MG, Suttle CA, Pledger RJ, Mitchell DL (1998b) Measurements of DNA damage and photoreactivation imply that most viruses in marine surface waters are infective. Aquat Microb Ecol 14:215-222

Wommack KE, Hill RT, Muller TA, Colwell RR (1996) Effects of sunlight on bacteriophage viability and structure. Appl Environ Microbiol 62:1336-1341

Worrest RC, Thomson BE, Van Dyke H (1981) Impact of UV-B radiation upon estuarine microcosms. Photochem Photobiol 33:861-867

Submitted: January 8, 1998; Accepted: August 28, 1998 Proofs received from author(s): May 10, 1999 